\title{
DIFUSI KOGNITIF REMAJA: KEBUTUHAN VIDEO TUTORIAL LATIHAN DIFUSI KOGNITIF
}

\author{
Gita Amelia ${ }^{1}$ \\ Eka Wahyuni ${ }^{2}$
}

\begin{abstract}
Abstrak
Penelitian ini bertujuan untuk mempelajari tingkat fusi kognitif remaja dan alat yang sesuai untuk memfasilitasi latihan difusi kognitif. Convenience sampling digunakan untuk mengumpulkan data dari 199 peserta didik. Instrumen yang digunakan adalah Cognitive Fusion Questionnaire (CFQ-7). Hasil penelitian menunjukkan bahwa $60 \%$ remaja mengalami fusi kognitif tinggi $(\mathrm{m}=29)$. Hasil tingkat fusi berdasarkan jenis kelamin, perempuan memiliki tingkat fusi yang lebih tinggi dibandingkan laki-laki (30 vs 28 ). Persentase perempuan yang mengalami fusi tingkat tinggi melebihi jumlah laki-laki (53\% vs 42\%). Hasil tingkat fusi berdasarkan sosial ekonomi, tingkat sosial ekonomi rendah memiliki tingkat fusi yang lebih tinggi dibandingkan sosial ekonomi tinggi (34 vs 29). Persentase sosial ekonomi rendah yang mengalami fusi tingkat tinggi melebihi jumlah sosial ekonomi tinggi (75\% vs $48 \%$ ). Sebagian besar peserta didik memiliki eksposur terbatas pada latihan difusi kognitif $(-70 \%)$ dan semuanya ingin belajar latihan difusi kognitif melalui video. Direkomendasikan bahwa video latihan difusi kognitif dibutuhkan untuk membantu peserta didik dalam meningkatkan kemampuan difusi kognitifnya.
\end{abstract}

Kata Kunci: Difusi Kognitif, Fusi Kognitif

\begin{abstract}
This study aims to explore the level of adolescents' cognitive fusion and suitable tools to facilitate cognitive defusion exercise. The convenience sampling used to gather the data from 199 students. The instrument used are the Cognitive Fusion Questionnaire (CFQ-7). The results showed that $60 \%$ of adolescents experienced high cognitive fusion $(m=29)$. The result of fusion level based on gender, female has higher level fusion than male (30 vs 28). The percentage of female who experience high level fusion was outnumber male (53\% vs 42\%). The result of fusion level based on sosial economy, low social economy higher level fusion than high social economy (34 vs 29). The percentage of low social economy who experience high level fusion was outnumber high social economy (75\% vs 48\%). Most of student has limited exposure to cognitive diffusion exercises (-70\%) and all of them eager to learn cognitive defusion exercises through video. It is recommended that cognitive defusion exercise video is needed to help student increase their cognitive defusion skill.
\end{abstract}

Keyword: Cognitive Defusion, Cognitive Fusion

\footnotetext{
${ }^{1}$ Universitas Negeri Jakarta, gitaamelia_1715161022@mhs.unj.ac.id/agitaamelia98@gmail.com

2 Universitas Negeri Jakarta, ewahyuni@unj.ac.id
} 


\section{PENDAHULUAN}

Individu memiliki kecenderungan untuk berpikir negatif, kurang percaya diri, dan memiliki emosi-emosi yang mengganggu. Menurut Ellis dalam Sasmita (2015), emosi negatif dinyatakan dalam bentuk kalimat (bahasa), yang terus menerus 'dimasukkan' pada diri hingga menjadi suatu keyakinan. Inilah yang disebut dengan irrational beliefs, yaitu keyakinan irasional yang terus-menerus dipercayai oleh individu dan ditanamkan ke dalam diri. Latihan yang dapat membantu mencegah dan mengurangi pikiran negatif secara berlebihan pada peserta didik disebut difusi kognitif. Latihan yang dapat membantu mencegah dan mengurangi pikiran negatif secara berlebihan pada peserta didik disebut difusi kognitif. Berdasarkan hasil penelitian yang dilakukan oleh Masuda dkk (2004) bahwa difusi kognitif dapat mengurangi pikiran negatif yang diyakini dan emosi-emosi yang mengganggu.

Difusi kognitif merupakan strategi untuk mengurangi fusi kognitif. Fusi kognitif merupakan suatu proses di mana seseorang menjadi terlalu menyatu, terikat, dan percaya terhadap pikiran mereka. Ketika kita menyatu dengan pikiran, kita akan melihat dunia dari pikiran. Seolaholah kita berada di dalam pikiran dan tidak dapat terpisah dari pikiran tersebut. Fusi dapat menyebabkan hilangnya kontak dengan peristiwa yang sesungguhnya, atau pengalaman nyata (Brown \& Gillard, 2016; Gillanders et al., 2014; Webster, 2011).

Tujuan difusi kognitif adalah untuk mengatasi fusi kognitif. Difusi kognitif juga dapat mengurangi pikiran negatif, kecemasan, dan kepercayaan diri peserta didik. Difusi kognitif dapat diterapkan untuk setiap masalah peserta didik yang diperburuk oleh keterikatan dengan isu kognitif (Luoma \& Hayes, 2003). Hal ini juga didukung dari hasil penelitian sebelumnya yang menyebutkan bahwa difusi kognitif dapat membantu masalahmasalah terkait isu fusi kognitif.
Penelitian sebelumnya terkait masalahmasalah yang berkaitan untuk meningkatkan difusi kognitif pada peserta didik yaitu tentang pikiran negatif, stres di tempat kerja, gangguan panik, kecemasan sosial, anoreksia, alkoholisme, kehilangan, eksibisionisme, gangguan kecemasan umum, pernyataan diri negatif, kurang percaya diri, pikiran negatif terhadap bentuk tubuh, keyakinan terhadap pikiran negatif, emosi-emosi yang mengganggu, psychological distress, dysphoria, dan harga diri yang rendah (Healy et al., 2008; Hinton \& Gaynor, 2010; Mandavia et al., 2015; Masuda et al., 2004; Saputra \& Prasetiawan, 2018).

Strategi untuk mengurangi fusi kognitif yaitu dengan melakukan latihan difusi kognitif yang disebut dengan floating leaves on a moving stream. Floating Leaves on a Moving Stream merupakan latihan difusi yang paling terkenal dan sering digunakan sebagai latihan untuk membantu kita menjauhkan diri dari aliran pikiran kita yang hampir konsisten atau pasti, untuk mundur dan mengamati pikiran kita daripada terjebak di dalamnya. Kita dapat melihat bahwa pikiran hanyalah pikiran, melewati aliran kata-kata yang tidak perlu bereaksi, kita hanya dapat memperhatikannya.

Latihan difusi kognitif akan dikembangkan dalam bentuk media video tutorial. Latihan difusi kognitif terdiri dari 4 tahapan, yaitu duduk pada posisi yang nyaman, berimajinasi di samping aliran sungai, melihat daun yang mengambang sebagai pikiran, dan hindari mempercepat atau memperlambat aliran sungai.

\section{Difusi Kognitif}

Difusi kognitif awalnya bernama 'cognitive distancing' pada tahun 1979 (Luoma \& Hayes, 2003). Difusi secara harfiah berarti memisahkan atau memberi jarak artinya adalah memisahkan atau memberi jarak terhadap pengalaman pribadi individu seperti emosi, persepsi serta dorongan dari diri individu. Selain itu, difusi berarti belajar untuk melangkah 
mundur dan memperlakukan pikiran, emosi, gambar, pengalaman, dan ingatan apa adanya tanpa mengurangi atau melebihkan (Boone \& Canicci, 2013; R Harris, 2009).

Difusi kognitif adalah suatu keterampilan untuk mengurangi penolakan terhadap pikiran atau pengalaman yang tidak menyenangkan. Selain itu, difusi kognitif merupakan suatu proses perubahan hubungan antara individu dan pikirannya dengan cara memperhatikan pikirannya ketika terjadi. Individu mengamati pikiran seolah-olah sebagai seorang pengamat, tanpa terjebak di dalamnya (Boone \& Canicci, 2013; R Harris, 2009; Russell Harris, 2006; Webster, 2011).

Difusi kognitif bertujuan untuk membantu peserta didik yang terperangkap atau terjebak dalam pikiran mereka sendiri dan berupaya untuk mengubah fungsi pikiran dan peristiwa pribadi lainnya yang tidak diinginkan, dan seharusnya menjadi lebih sadar akan berpikir sebagai proses hubungan yang aktif, berkelanjutan, dan tersimpan baik secara historis maupun situasional. Difusi kognitif dapat diterapkan untuk setiap masalah peserta didik yang diperburuk oleh keterikatan dengan isu kognitif. Dengan kata lain, difusi kognitif berupaya untuk mengubah cara seseorang dalam berinteraksi atau berhubungan dengan pikiran dan menciptakan konteks dimana memperlakukan pikiran apa adanya tanpa mengurangi atau melebihkan (Boone \& Canicci, 2013; Hayes et al., 2006; Luoma $\&$ Hayes, 2003).

Difusi kognitif merupakan strategi untuk mengatasi fusi kognitif. Fusi kognitif merupakan suatu proses di mana seseorang menjadi terlalu menyatu, terikat, dan percaya terhadap pikiran mereka. Ketika kita menyatu dengan pikiran, kita akan melihat dunia dari pikiran. Seolah-olah kita berada di dalam pikiran dan tidak dapat terpisah dari pikiran tersebut. Fusi dapat menyebabkan hilangnya kontak dengan peristiwa yang sesungguhnya, atau pengalaman nyata (Brown \& Gillard, 2016; Gillanders et al., 2014; Webster, 2011).
Difusi kognitif menekankan bahwa pikiran hanyalah suatu pikiran, bukan suatu kebenaran literal yang dengan pikiran kita harus hidup. Difusi kognitif dapat membantu peserta didik untuk merekognisi kebenaran pemikirannya yang hanya berupa pikiran negatif atau pikiran yang menyatu. Salah satu latihan difusi kognitif yang digunakan untuk menciptakan jarak pada pikiran yang terjebak adalah Floating Leaves on a Moving Stream.

Floating Leaves on a Moving Stream merupakan latihan yang mengajarkan dan melatih individu bahwa pikiran atau pengalaman tidak menyenangkan dapat diartikan sebagai daun gugur yang dapat jatuh begitu saja pada aliran sungai, dimana mereka dapat muncul dalam pemikiran kita kapanpun dia mau, namun ia tidak selamanya berada disana karena arus pikiran kita yang mengalir dengan deras (Hayes, 2005).

Tahapan floating leaves on a moving stream yang diberikan oleh Hayes (2005) sebagai berikut: 1) Duduk pada posisi yang nyaman; 2) Berimajinasi di samping aliran sungai; 3) Melihat daun yang mengambang sebagai pikiran; 4) Hindari mempercepat atau memperlambat aliran sungai.

\section{METODE PENELITIAN}

Penelitian ini bertujuan untuk mengetahui tingkat fusi kognitif remaja dan kebutuhan video tutorial latihan difusi kognitif sebagai strategi mengurangi pikiran negatif untuk remaja. Penelitian dilaksanakan pada salah satu SMA Negeri di Jakarta Pusat. Penelitian ini menggunakan metode survey.

Populasi penelitian merupakan peserta didik kelas XI sebanyak 160 dengan sampel sebanyak 119 menggunakan sampel probability sampling dengan teknik convenience sampling. Berikut karakteristik sample yang didapatkan dari 119 peserta didik: 


\begin{tabular}{|c|c|c|c|}
\hline \multirow{2}{*}{$\begin{array}{c}\text { Jenis } \\
\text { kelamin }\end{array}$} & Perempuan & 76 & $63,8 \%$ \\
\hline & Laki-laki & 43 & $36,1 \%$ \\
\hline \multirow{2}{*}{$\begin{array}{l}\text { Kelas } \\
\text { sosial }\end{array}$} & Menengah-Tinggi & 115 & $96,6 \%$ \\
\hline & Rendah & 4 & $3,3 \%$ \\
\hline
\end{tabular}

Tabel 1. Karakteristik Sampel

Berdasarkan tabel 1, dari 119 peserta didik sebanyak 76 peserta didik berjenis kelamin perempuan dengan persentase sebesar $63,8 \%$ dan sebanyak 43 peserta didik berjenis kelamin laki-laki dengan persentase sebesar 36,1\%. Sedangkan berdasarkan kelas sosial dari 119 peserta didik sebanyak 115 peserta didik berada pada kelas sosial menengah-tinggi dengan persentase sebesar $96,6 \%$ dan sebanyak 4 peserta didik berada pada kelas sosial rendah dengan persentase sebesar 3,3\%.

Dalam penelitian ini, data dikumpulkan menggunakan instrumen mengenai fusi kognitif. Instrumen yang digunakan adalah Cognitive Fusion Questionnaire (CFQ-7) Gillanders dkk tahun 2014. Sebelum mendapatkan instrumen untuk pengumpulan data, dilakukan adaptasi instrumen asli kedalam bahasa indonesia.

Langkah-langkah adaptasi instrumen Menurut (Hambleton, Merenda, dan Spielberger, 2005) yaitu Menerjemahkan instrumen kedalam bahasa yang digunakan, Evaluasi dari versi instrumen yang telah disintesis oleh ahli, Back-Translation, dan Uji Coba Instrumen dan Validitas Instrumen.

Alat ukur untuk fusi kognitif yang digunakan dalam penelitian ini adalah Cognitive Fusion Questionnaire (CFQ) Gillanders dkk tahun 2014. Alat ukur ini terdiri dari 7 indikator yaitu termasuk bereaksi secara emosional terhadap pikiran, perilaku diatur oleh pikiran, terlalu berlebihan dari menganalisis situasi, mencoba mengontrol pikiran, mengevaluasi isi pikiran, kesadaran pikiran yang terpisah, dan dominasi kognisi dalam pengalaman seseorang.

Alat ukur ini merupakan pembaharuan dari alat ukur sebelumnya yaitu CFQ-44,
CFQ-15, CFQ-13 dari Dempster (2009). CFQ-7 terdiri dari 7 item kuesioner yang dinilai pada skala 7 poin yang memiliki total skor masing-masing. Menggunakan skala Likert yang terdiri dari tujuh skala yaitu skala 1 tujuh poin tipe likert dari (tidak pernah benar) hingga 7 (selalu benar) dengan skor minimal 7 dan skor maksimal 49.

\section{HASIL PENELITIAN}

Dari penelitian yang telah dilakukan mendapatkan hasil bahwa fusi kognitif pada remaja SMA Negeri di Jakarta menggunakan CFQ-7 berada pada kategori tinggi. Rata-rata skor yang diperoleh sebesar 29 dari total skor 49 dan persentase sebesar $60 \%$, dengan jumlah responden sebanyak 119 peserta didik.

Peserta didik yang berada pada kategori tinggi diinterprestasikan bahwa mereka cepat beraksi secara emosional dan perilaku yang dipengaruhi oleh pikiran yang telah bercampur (fusi), menganalisis situasi secara terlalu berlebihan, dan sulit mengontrol pikiran.

Kategori tinggi pada CFQ-7 dengan interpretasi peserta didik terlalu bereaksi secara emosional terhadap pikiran, perilaku diatur oleh pikiran, terlalu berlebihan dalam menganalisis situasi, sulit mengontrol pikiran, terlalu mengevaluasi isi pikiran, kesadaran pikiran yang terpisah, dan terlalu mendominasi kognisi dalam pengalaman seseorang.

Berikut hasil rata-rata dan standar deviasi dari aspek Cognitive Fusion Questionnaire:

\begin{tabular}{lcc}
\hline & Rerata & SD \\
$\begin{array}{l}\text { Total } \\
\text { Bereaksi secara emosional terhadap } \\
\text { pikiran }\end{array}$ & 4,3 & 1,5 \\
Perilaku diatur oleh pikiran & 4,4 & 1,4 \\
$\begin{array}{l}\text { Terlalu berlebihan dari menganalisis } \\
\text { situasi }\end{array}$ & 4,8 & 1,6 \\
$\begin{array}{l}\text { Mencoba mengontrol pikiran } \\
\text { Mengevaluasi isi pikiran }\end{array}$ & 3,97 & 1,5 \\
$\begin{array}{l}\text { Kesadaran pikiran yang terpisah } \\
\text { Dominasi kognisi dalam }\end{array}$ & 3 & 1,77 \\
pengalaman seseorang & 4,2 & 1,6 \\
\hline
\end{tabular}

Tabel 2. Rerata dan Standar Deviasi 
Berdasarkan tabel 2, terlihat bahwa pada aspek terlalu berlebihan dari menganalisis sesuatu lebih tinggi daripada aspek lain dengan rata-rata (mean) 4,8 yang artinya peserta didik terlalu berlebihan dalam menganalisis situasi sampai pada titik bahwa hal itu tidak membantunya.

Berdasarkan tabel 2, didapatkan nilai rata-rata (mean) pada aspek bereaksi secara emosional terhadap pikiran sebesar 4,3 dengan standar deviasi sebesar 1,5. Pada aspek perilaku diatur oleh pikiran didapatkan mean sebesar 4,4 dengan standar deviasi sebesar 1,4. Pada aspek terlalu berlebihan dari menganalisis situasi didapatkan mean sebesar 4,8 dengan standar deviasi sebesar 1,6. Pada aspek mencoba mengontrol pikiran didapatkan mean sebesar 3,97 dengan standar deviasi sebesar 1,5. Pada aspek mengevaluasi isi pikiran didapatkan mean sebesar 4 dengan standar deviasi sebesar 1,77. Pada aspek kesadaran pikiran yang terpisah didapatkan mean sebesar 3,7 dengan standar deviasi sebesar 1,6. Pada aspek dominasi kognisi dalam pengalaman seseorang didapatkan mean sebesar 4,2 dengan standar deviasi sebesar 1,78. Dapat disimpulkan bahwa data kurang bervariasi karena nilai standar deviasi lebih kecil daripada mean.

Berdasarkan hasil studi pendahuluan Cognitive Fusion Questionnaire yang diberikan kepada 119 peserta didik didapatkan total skor yaitu 3481. Hasil ratarata skor yaitu 29 dari total skor 49 yang berarti peserta didik memiliki fusi kognitif pada kategori tinggi. Peserta didik yang berjenis kelamin perempuan sebanyak 76 orang dan laki-laki sebanyak 43 orang. Peserta didik yang berada di kelas menengah-tinggi sebanyak 115 orang dan kelas rendah sebanyak 4 orang.

Pada peserta didik berjenis kelamin perempuan dengan rata-rata (mean) keseluruhan sebesar 30 berada pada tingkat tinggi. Pada fusi kognitif kategori tinggi memiliki rata-rata (mean) sebesar 36 berada pada tingkat tinggi dengan responden sebanyak 40 peserta didik dan persentase sebesar 53\%. Pada fusi kognitif kategori rendah memiliki rata-rata (mean) sebesar 23 berada pada tingkat rendah dengan responden sebanyak 36 peserta didik dan persentase sebesar $47 \%$.

Pada peserta didik berjenis kelamin laki-laki dengan rata-rata (mean) keseluruhan sebesar 28 berada pada tingkat rendah. Pada fusi kognitif kategori tinggi memiliki rata-rata (mean) sebesar 34 berada pada tingkat tinggi dengan responden sebanyak 18 peserta didik dan persentase sebesar $42 \%$. Pada fusi kognitif kategori rendah memiliki rata-rata (mean) sebesar 23 berada pada tingkat rendah dengan responden sebanyak 25 peserta didik dan persentase sebesar $58 \%$.

Tingkat fusi kognitif ditinjau dari jenis kelamin laki-laki dan perempuan menunjukkan bahwa perempuan memiliki fusi kognitif yang lebih tinggi. Hal ini didukung dari hasil penelitian yang dilakukan oleh Dinis dkk (2015) bahwa wanita lebih terjerat dengan isi pikiran mereka (fusi kognitif). Menurut BenettiMcQuoid \& Bursik (2005) dalam Dinis dkk (2015) mengidentifikasi peran gender dan ciri-ciri kepribadian yang terkait dengan setiap gender yaitu, kemandirian, kepercayaan dan ketegasan pada laki-laki, dan kepekaan terhadap kebutuhan orang lain, serta kesadaran perasaan pada perempuan).

Berikut tabel yang menggambarkan profil tingkat fusi kognitif berdasarkan jenis kelamin:

\begin{tabular}{lccccc}
\hline & \multicolumn{4}{c}{ Fusi Kognitif } \\
\cline { 3 - 6 } & \multirow{2}{*}{ Rerata } & \multicolumn{2}{c}{ Tinggi } & \multicolumn{3}{c}{ Rendah } \\
\cline { 3 - 6 } & & $F$ & $\%$ & $F$ & $\%$ \\
\hline Laki-laki & 28 & 18 & 42 & 25 & 58 \\
Perempuan & 30 & 40 & 53 & 36 & 47 \\
\hline
\end{tabular}

Tabel 3. Profil Tingkat Fusi Kognitif Berdasarkan Jenis kelamin

Pada peserta didik kelas sosial rendah dengan rata-rata (mean) keseluruhan sebesar 34 berada pada tingkat tinggi. Pada fusi kognitif kategori tinggi memiliki rata- 
rata (mean) sebesar 37 berada pada tingkat tinggi dengan responden sebanyak 3 peserta didik dan persentase sebesar $75 \%$. Pada fusi kognitif kategori rendah memiliki rata-rata (mean) sebesar 25 berada pada tingkat rendah dengan responden sebanyak 1 peserta didik dan persentase sebesar $25 \%$.

Pada peserta didik kelas sosial tinggi dengan rata-rata (mean) keseluruhan sebesar 29 berada pada tingkat tinggi. Pada fusi kognitif kategori tinggi memiliki ratarata (mean) sebesar 36 berada pada tingkat tinggi dengan responden sebanyak 55 peserta didik dan persentase sebesar $48 \%$. Pada fusi kognitif kategori rendah memiliki rata-rata (mean) sebesar 23 berada pada tingkat rendah dengan responden sebanyak 60 peserta didik dan persentase sebesar $52 \%$.

Tingkat fusi kognitif ditinjau dari kelas sosial tinggi dan rendah menunjukkan bahwa kelas sosial rendah memiliki fusi kognitif yang lebih tinggi. Hal ini didukung dari hasil penelitian yang dilakukan oleh Sinthia (2011) bahwa penerimaan sosial kelompok kelas masih ditemukan tingkat penerimaan kelompok kelas rendah $(17,5 \%)$ dan sangat rendah $(1,84 \%)$. Hal ini dapat disebabkan peserta didik tidak dapat bekerjasama, sifat kepribadian yang menggangu orang lain seperti mementingkan diri sendiri, keras kepala dan mudah marah. Dengan demikian, tingkat fusi kognitif pada peserta didik berkaitan dengan kelas sosial yag dimiliki.

Berikut tabel yang menggambarkan profil tingkat fusi kognitif berdasarkan kelas sosial:

\begin{tabular}{lccccc}
\hline & & \multicolumn{4}{c}{ Fusi Kognitif } \\
\cline { 3 - 6 } & Rerata & \multicolumn{2}{c}{ Tinggi } & \multicolumn{3}{c}{ Rendah } \\
\cline { 3 - 6 } & 34 & 3 & 75 & 1 & 25 \\
\hline $\begin{array}{l}\text { Kelas sosial } \\
\text { rendah }\end{array}$ & 29 & 55 & 48 & 60 & 52 \\
$\begin{array}{l}\text { Kelas sosial } \\
\text { tinggi }\end{array}$ & & & & & \\
\hline
\end{tabular}

Tabel 4. Profil Tingkat Fusi Kognitif Berdasarkan Kelas Sosial

Berdasarkan hasil studi pendahuluan yang dilakukan bahwa sebanyak $70 \%$ peserta didik belum pernah mendapatkan materi mengenai strategi mengurangi pikiran negatif, sebanyak $57 \%$ peserta didik belum pernah mendapatkan materi mengenai strategi mengurangi pikiran negatif, sebanyak $63 \%$ peserta didik belum pernah menggunakan video tutorial sebagai strategi mengurangi pikiran negatif, dan sebanyak $100 \%$ peserta didik menyatakan bahwa sangat perlu dan setuju jika dikembangkannya media video tutorial strategi mengurangi pikiran negatif sebagai media bimbingan yang digunakan oleh guru bimbingan dan konseling.

Video tutorial latihan difusi kognitif membantu peserta didik untuk lebih mengenali dan memahami strategi mengurangi pikiran negatif (fusi) yang dapat dilakukan secara mandiri. Selain itu, video tutorial ini dapat membantu guru BK dalam memberikan layanan bimbingan dan konseling serta dapat menjadi media alternatif yang digunakan oleh guru Bimbingan dan Konseling/konselor selain media yang sudah ada sebelumnya untuk menarik perhatian peserta didik.

Beberapa saran yang dapat dijadikan pertimbangan berdasarkan hasil penelitian diatas yaitu bagi peneliti selanjutnya dapat melanjutkan proses penelitian ini dengan menjadikan hasil penelitian tentang tingkat fusi kognitif sebagai rujukan dalam pengembangan media dan uji coba media video tutorial kepada peserta didik, sehingga dapat diketahui keefektifannya jika diimplementasikan saat kegiatan bimbingan dan konseling. Bagi guru Bimbingan dan Konseling/konselor, hasil penelitian dan video tutorial ini dapat digunakan untuk membantu peserta didik yang memiliki fusi kognitif dengan memberikan layanan mengenai materi ataupun latihan difusi kognitif.

\section{KESIMPULAN}

Berdasarkan hasil penelitian yang telah dilakukan oleh peneliti, dapat disimpulkan bahwa sebanyak 119 peserta didik pada salah satu SMA Negeri di Jakarta Pusat memiliki tingkat fusi kognitif pada kategori 
tinggi dengan rata-rata skor 29 dari total skor 49 dan persentase sebesar $60 \%$.

Hal ini menunjukkan bahwa peserta didik cepat beraksi secara emosional dan perilaku yang dipengaruhi oleh pikiran yang telah bercampur (fusi), menganalisis situasi secara terlalu berlebihan, dan sulit mengontrol pikiran.

\section{DAFTAR PUSTAKA}

Boone, M. S., \& Canicci, J. (2013). Acceptance and Commitment Therapy (ACT) in Groups. In J. Pistorello (Ed.), Mindfulness and acceptance for counseling college students: theory and practical applications for intervention, prevention, and outreach. Context Press, An Imprint of New Harbinger Publications.

Brown, F. J., \& Gillard, D. (2016). Acceptance and commitment therapy for dummies. John Wiley \& Sons, Ltd.

Dempster, M. A. (2009). Development and initial validation of a scale to measure cognitive fusion. PQDT - UK \& Ireland, February, 1. https://search.proquest.com/docview/1 040635056? accountid $=14166 \% 0$ Ahttp ://xg9ax2jm9j.search.serialssolutions.c om?ctx_ver=Z39.88-

2004\&ctx_enc=info:ofi/enc:UTF-

$8 \&$ rfr_id=info:sid/ProQuest+Dissertat ions+\%26+Theses+Global\&rft_val_f mt=info:ofi/fmt:kev:mtx:dissert

Dinis, A., Carvalho, S. A., Pinto Gouveia, J., \& Estanqueiro, C. (2015). Shame memories and depression symptoms: The role of cognitive fusion and experiential avoidance. International Journal of Psychology and Psychological Therapy, 15(1), 63-86.

Gillanders, D. T., Bolderston, H., Bond, F. W., Dempster, M., Flaxman, P. E., Campbell, L., Kerr, S., Tansey, L., Noel, P., Ferenbach, C., Masley, S., Roach, L., Lloyd, J., May, L., Clarke, S., \& Remington, B. (2014). The Development and Initial Validation of the Cognitive Fusion Questionnaire. Behavior Therapy, 45(1), 83-101. https://doi.org/10.1016/j.beth.2013.09. 001

Hambleton, R. K., Merenda, P. F., \& Spielberger, C. D. (2005). Adapting Educational and Psychological Tests for Cross-Cultural Assessment. Lawrence Erlbaum Associates Publishers.

Harris, R. (2009). ACT made imple: an easy-to-read primer on acceptance and commitment therapy. New Harbinger Publications. papers2://publication/uuid/464225D2A6DA-4034-ACFB-179650B573C3

Harris, Russell. (2006). Embracing your demons: An overview of acceptance and commitment therapy. Psychotherapy in Australia, 12(4), 28.

Hayes, S. C. (2005). Get out of your mind and into ypur life: The new acceptance and commitment therapy. New Harbinger Publications.

Hayes, S. C., Luoma, J., Bond, F. W., Masuda, A., \& Lillis, J. (2006). Acceptance and commitment therapy: Model, processes, and outcomes. Psychology Faculty Publications, 130. https://doi.org/10.4324/978131574513 8

Healy, H. A., Barnes-Holmes, Y., BarnesHolmes, D., Keogh, C., Luciano, C., \& Wilson, K. (2008). An experimental test of a cognitive defusion exercise: Coping with negative and positive self-statements. Psychological Record, 58(4), 623-640. https://doi.org/10.1007/BF03395641

Hinton, M. J., \& Gaynor, S. T. (2010). Cognitive defusion for psychological distress, dysphoria, and low selfesteem: A randomized technique evaluation trial of vocalizing strategies. International Journal of Behavioral Consultation and Therapy, 6(3), 164-185. https://doi.org/10.1037/h0100906

Luoma, J. B., \& Hayes, S. C. (2003). Cognitive Defusion. In W. 
O'Donohue, J. E. Fisher, \& S. C. Hayes (Eds.), Cognitive behavior therapy: applying empirically supported techniques in your practice. John Wiley \& Sons. https://doi.org/10.1201/978131538079 7

Mandavia, A., Masuda, A., Moore, M., Mendoza, H., Donati, M. R., \& Cohen, L. L. (2015). The application of a cognitive defusion technique to negative body image thoughts: A preliminary analogue investigation. Journal of Contextual Behavioral Science, 4(2), 86-95. https://doi.org/10.1016/j.jcbs.2015.02. 003

Masuda, A., Hayes, S. C., Sackett, C. F., \& Twohig, M. P. (2004). Cognitive defusion and self-relevant negative thoughts: Examining the impact of a ninety year old technique. Behaviour Research and Therapy, 42(4), 477485.

https://doi.org/10.1016/j.brat.2003.10. 008

Saputra, W. N. E., \& Prasetiawan, H. (2018). Meningkatkan percaya diri siswa melalui teknik cognitive defusion. Jurnal Kajian Bimbingan Dan Konseling, 3(1), 14-21. https://doi.org/10.17977/um001v3i120 $18 \mathrm{p} 014$

Sasmita, P. E. (2015). Irrational beliefs dalam konteks kehidupan seminari. Jurnal Teologi, 04(01), 25-40.

Sinthia, R. (2011). Hubungan Antara Penerimaan Sosial Kelompok Kelas Dengan Kepercayaan Diri Pada Siswa Kelas I Sltp Xxx Jakarta. Jurnal
Kependidikan Triadik, 14(1), 37-44.

Webster, M. (2011). Introduction to acceptance and commitment therapy. Advances in Psychiatric Treatment, 17(4), 309-316. https://doi.org/10.1192/apt.bp.107.005 256 


\section{Lampiran}

Instrumen Cognitive Fusion Questionnaire

\section{Cognitive Fusion Questionnaire}

Mohon diisi sesuai kondisi kalian saat ini. Angket ini terdiri dari tujuh pernyataan dan dengan tujuh pilihan jawaban, yaitu:

1 : Tidak Pernah Benar

2 : Sangat Jarang Benar

3 : Jarang Benar

4. Terkadang Benar

5. Sering Benar

6. Hampir Selalu Benar

7. Selalu Benar

Beri tanda silang $(\mathrm{X})$ pilihan jawaban yang sesuai dengan kalian.

\begin{tabular}{|l|l|l|l|l|l|l|l|l|}
\hline No. & \multicolumn{1}{|c|}{ Pernyataan } & $\mathbf{1}$ & $\mathbf{2}$ & $\mathbf{3}$ & $\mathbf{4}$ & $\mathbf{5}$ & $\mathbf{6}$ & $\mathbf{7}$ \\
\hline 1. & $\begin{array}{l}\text { Pikiran-pikiran saya membuat saya } \\
\text { tertekan dan sakit secara emosi }\end{array}$ & 1 & 2 & 3 & 4 & 5 & 6 & 7 \\
\hline 2. & $\begin{array}{l}\text { Saya sangat terperangkap dengan } \\
\text { pikiran-pikiran saya sehingga saya } \\
\text { tidak bisa mengerjakan hal-hal yang } \\
\text { sangat ingin saya lakukan }\end{array}$ & 1 & 2 & 3 & 4 & 5 & 6 & 7 \\
\hline 3. & $\begin{array}{l}\text { Saya terlalu berlebihan menganalisis } \\
\text { situasi sampai pada titik bahwa hal itu } \\
\text { tidak membantu saya }\end{array}$ & 1 & 2 & 3 & 4 & 5 & 6 & 7 \\
\hline 4. & $\begin{array}{l}\text { Saya kesulitan mengontrol pikiran- } \\
\text { pikiran saya }\end{array}$ & 1 & 2 & 3 & 4 & 5 & 6 & 7 \\
\hline 5. & $\begin{array}{l}\text { Saya marah dengan diri saya sendiri } \\
\text { karena saya memiliki pikiran-pikiran } \\
\text { tertentu }\end{array}$ & 1 & 2 & 3 & 4 & 5 & 6 & 7 \\
\hline 6. & $\begin{array}{l}\text { Saya cenderung merasa terbelenggu } \\
\text { dengan pikiran-pikiran saya }\end{array}$ & 1 & 2 & 3 & 4 & 5 & 6 & 7 \\
\hline 7. & $\begin{array}{l}\text { Sungguh hal yang sulit bagi saya untuk } \\
\text { melepaskan pikiran yang mengesalkan } \\
\text { walau saya tahu dengan melepaskan } \\
\text { akan membantu saya }\end{array}$ & 1 & 2 & 3 & 4 & 5 & 6 & 7 \\
\hline
\end{tabular}

